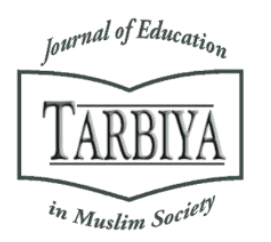

Available online at TARBIYA: Journal of Education in Muslim Society Website:

http://journal.uinjkt.ac.id/index.php/tarbiya

TARBIYA: Journal of Education in Muslim Society, 4(2), 2017, 176-183

\title{
AN ANALYSIS ON PEDAGOGY CONTENT ISLAMIC KNOWLEDGE OF INDONESIAN QUALIFICATION FRAMEWORK IN BIOLOGY EDUCATION PROGRAM
}

\author{
Yanti Herlanti \\ Syarif Hidayatullah State Islamic University of Jakarta, Indonesia \\ E-mail: yantiherlanti@uinjkt.ac.id
}

Received: $10^{\text {th }}$ September 2017; Revised: $15^{\text {th }}$ October 2017; Accepted: $27^{\text {th }}$ December 2017

\section{Abstract}

This study aims to analyze Pedagogy Content Islamic Knowledge (PCIK) on the Indonesian Qualification Framework (IQF) in Biology Education Study Program. The competence in Pedagogy Content Knowledge (PCK) is the achievement of Biology Education Program. The challenge faced by the Biology Education programs belong to Islamic colleges and universities is to combine the program with the knowledge of Islam. The graduates of Biology Education program are required to master the Pedagogy Content Islamic Knowledge (PCIK). PCIK analysis was conducted qualitatively on Biology Islamic Education curriculum document at three state Islamic universities in Indonesia. The subjects of the study were three heads of study program, fourteen lecturers, and sixteen students. In-depth interviews, questionnaires, and discussions were conducted on the subjects. The results showed that PCIK is conceptually and textually seen in three subjects, namely capita selecta, microteaching practice, and school field practice. PCIK appeared in the scientific process, i.e. critical reflective activity on the significance of natural phenomena created by God.

Keywords: PCIK; IQF; Biology Islamic Education

\section{Abstrak}

Penelitian ini bertujuan untuk menganalisis Pedagogy Content Islamic Knowledge (PCIK) pada Kerangka Kualifikasi Nasional Indonesia (KKNI) Program Studi Tadris Biologi. Kemampuan Pedagogy Content Knowledge (PCK) merupakan capaian Program Studi Pendidikan Biologi. Bagi program studi Tadris Biologi di bawah naungan PTKI (Perguruan Tinggi Keagamaan Islam) memiliki tantangan satu tantangan lagi yaitu memadukan dengan pengetahuan islam. Keluaran dari Tadris Biologi dituntut kemampuan Pedagogy Content Islamic Knowledge (PCIK). Analisis PCIK dilakukan secara kualitatif terhadap dokumen kurikulum Tadris Biologi pada tiga UIN di Indonesia. Selain itu dilakukan wawancara mendalam, pengisian angket, dan diskusi terpumpun bersama narasumber yaitu tiga orang ketua program studi, empat belas dosen, dan enam belas mahasiswa. Hasil penelitian menunjukkan PCIK secara tekstual konseptual terlihat pada tiga matakuliah yaitu kapita selekta, praktik pengajaran mikro, dan praktik lapangan madrasah. PCIK muncul pada proses sains berupa kegiatan reflektif kritis terhadap hakekat fenomena alam yang diciptakan oleh Alloh swt.

Kata kunci: PCIK; KKNI; Tadris Biologi

How to Cite : Herlanti, Y. (2017). An Analysis on Pedagogy Content Islamic Knowledge of Indonesian Qualification Framework in Biology Islamic Education Program. TARBIYA: Journal of Education in Muslim Society, 4(2), 176-183. doi:10.15408/tjems.v4i2.6751.

Permalink/DOI: http://dx.doi.org/10.15408/tjems.v4i2.6751

TARBIYA: Journal of Education in Muslim Society, P-ISSN: 2356-1416, e-ISSN: 2442-9848

This is an open access article under CC-BY-SA license (https://creativecommons.org/licenses/by-sa/4.0/) 


\section{Introduction}

The competence in Pedagogy Content Knowledge (PCK) is one of the learning objectives in Biology education study program on IQF (ASPBI, 2016; ALPTKI, 2013). PCK is an acknowledgement to the importance of the transformation of subject matter knowledge into subject matter knowledge for teaching (Park \& Oliver, 2008).

PCK is a general skill-set that collectively focuses on the overlap part between the Pedagogy Knowledge (PK) and Content Knowledge (CK), how individual topics of subject knowledge are systematized, modified, and exemplified for classroon teaching (Song, 2017). CK is teacher's perception of teaching the subject matter, and PCK is teacher's required knowledge to make the subject matter accessible to students (Kazemi \& Rafiepour, 2017). Biology has a special standing concerning teachers' CK, biology includes substantive and syntactic structures. Substantive structures suggest ways of organizing biological concepts and principles. Syntactic structures indicate ways by which extremes such as truth and falsehood are established (Juttner, et al., 2013).

The term PCK emerged when Shulman (1987) conducted an observation to several teachers explaining photosynthesis topics. It appeared that the teachers combined content knowledge and pedagogical strategy. It was obvious that PCK competence was immersed in the teachers' mind while teaching. In explaining photosynthesis topics to senior high school students, teachers used a diagram of photosynthesis process to simplify the complicated and abstract concepts. However, when the teachers taught the similar concepts to elementary school students, they used a simple picture of leaves as an analogy of kitchen. During delivering the content, it is necessary for the teachers to adapt to several factors, i.e. from the age of the learners, the avilable facilities and infrastructures, as well as the psychological and social condition of the learners. The ability in delivering Biology content in accodarnce with the learners' condition is called PCK competence. Widi et al (2010) stated that PCK competence is ability in knowing science and how to teach it. PCK is a necessary body of knowledge for reformed science teaching (Park, et al., 2011).

However, PCK is not adequate for Biology education program under The Ministry of Religious Affairs. Thus, an ability which integrates with Islamic knowledge or Pedagogy Content Islamic Knowledge (PCIK) is necessary.

PCIK has a meaning that integrates the knowledge of Islam in PCK. According to Anas et al. (2013) there were three foundations in the knowledge of Islam, i.e. creed (akidah), sharia, and morals (akhlak). Creed (akidah) is related to faith or belief. Meanwhile, sharia is related to norms or laws. Whereas, morals (akhlak) is related to behavior. The three foundations depict the vertical relationship with the Creator (God), the horizontal relationship with human beings and the other creatures of God.

Generally, Islamic colleges and universities has a vision which reflects their Islamic integrity in their academic activities. Syarif Hidayatullah State Islamic University Jakarta has a vision to become a world-class university by the integration of science, Islamic values, and Indonesian-ness ${ }^{1}$. State Islamic University Yogyakarta vision is to become a leading and excellent institution in the development of Islamic economic and business for the advancement of civilization ${ }^{2}$. State Islamic University Bandung vision is to make an excellent and competitive university in ASEAN

\footnotetext{
${ }^{1}$ UIN Syarif Hidayatullah Jakarta. Visi Misi Tujuan. Retrieved from: http://www.uinjkt.ac.id/visi-misi-dan-tujuan/

${ }^{2}$ UIN Sunan Kalijanga. Visi Misi Tujuan. Retrieved from: http://uinsuka.ac.id/id/web/page/universitas/2-visi-misi-tujuan
} 
in 2025 which integrating and developing Islamic studies with the contemporary sciences based on the paradigm: revelations guide science $^{3}$. Based on the visions of the three universities, it is obvious that the development of PCIK is really essential in Biology education program curriculum.

The study aims to analyze PCIK in Biology education curriculum as well as to provide some recommendations for its development practices.

\section{Method}

Qualitative methods was used in this study. Table 1 showed the data, data sources and collection methods.

Table 1. Data, Data Sources, and Data Collection Methods

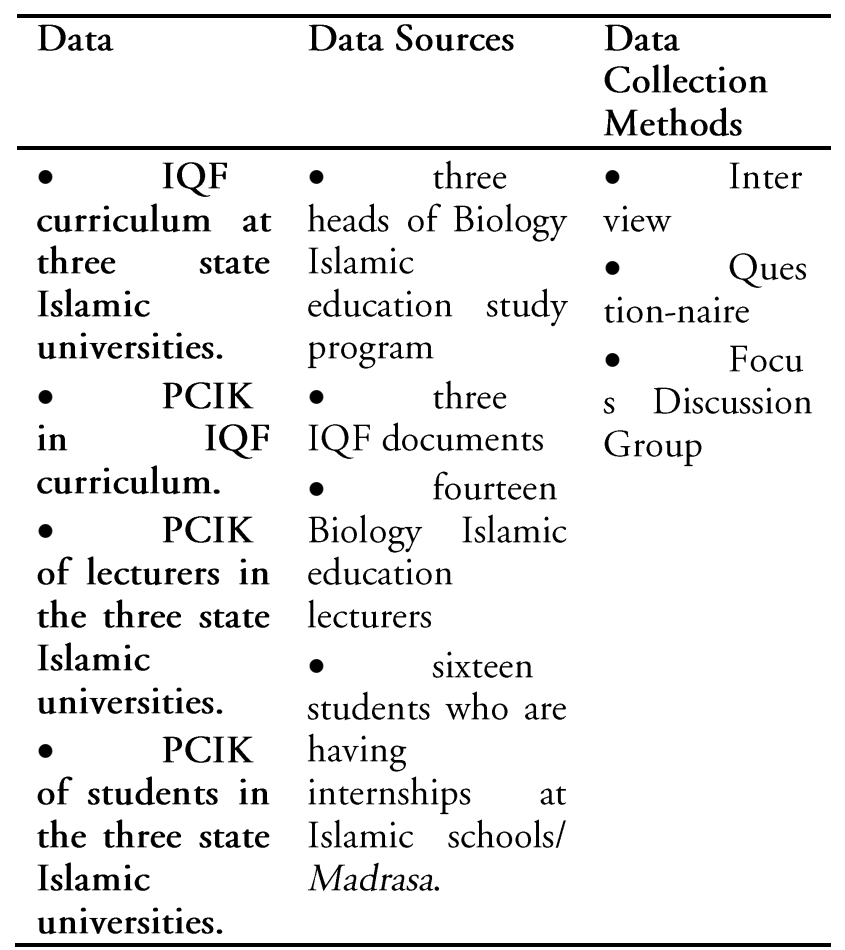

The data analysis used interactive model which consists of data reduction, data display

${ }^{3}$ UIN Sunan Gunung Djati. (2016). Visi dan Misi. Retrieved from: http://www.uinsgd.ac.id/front/arsip/page/kampus/visi-dan-misi and conclusions drawing (Sugiyono, 2012). Figure 1 shows the data analysis.

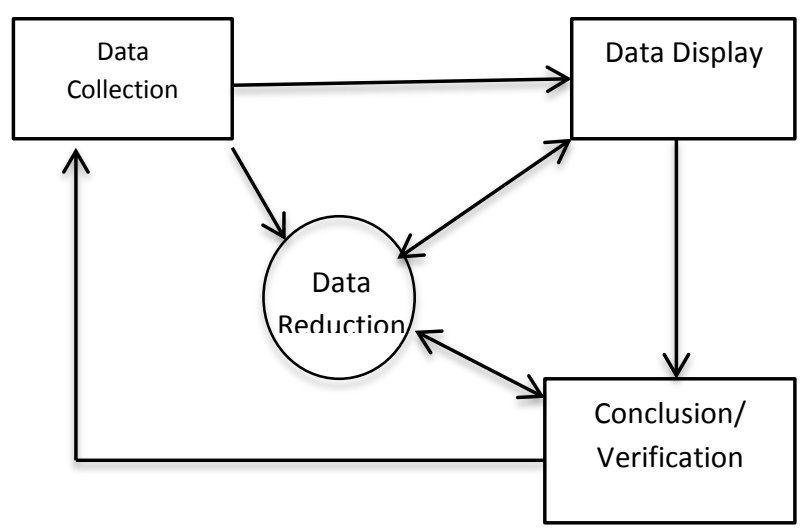

Figure 1. Analysis Technique of

Qualitative Data

The research object is curriculum document of tadris biology from three Islamic university in Jakarta, Bandung, and Yogyakarta. The research involved three head officer of tadris biology, Four teen lectures of tadris biology, and four teen students of tadris biology who have taken practical teaching in higher islamic school or madrasah aliyah. Table 2 show the informan that involved in this research.

Table 2. The Informan of Reasearch

\begin{tabular}{lllll}
\hline University & $\begin{array}{l}\text { Head } \\
\text { Officer }\end{array}$ & Lectures & Students & Sum \\
\hline $\mathbf{1}$ & 1 & 4 & 5 & 10 \\
2 & 1 & 4 & 6 & 11 \\
$\mathbf{3}$ & 1 & 6 & 5 & 12 \\
Sum & 3 & 14 & 16 & 33 \\
\hline
\end{tabular}

\section{Findings and Discussion}

\section{Findings}

Textual analysis of curriculum documents showed the course subjects was classified into five groups. The groups are content knowledge (CK), pedagogy knowledge (PK), islamic knowledge (IK), pedagogy content knowledge (PCK), and pedagogy content islamic knowledge (PCIK). Table 3-7 showed the results of curiculum documents analysis. 
Based on the validated documents vaidated by the head of study program, the textual results showed there were three models of the curriculum integration in the three universities. The models can be seen in Figure 2.
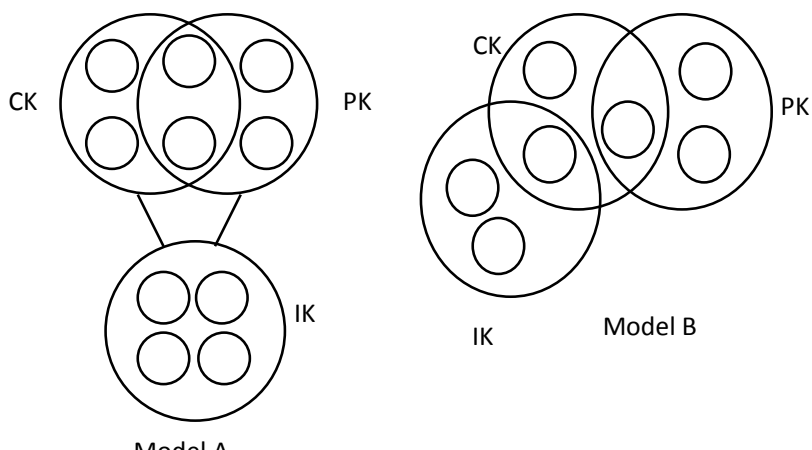

Model A

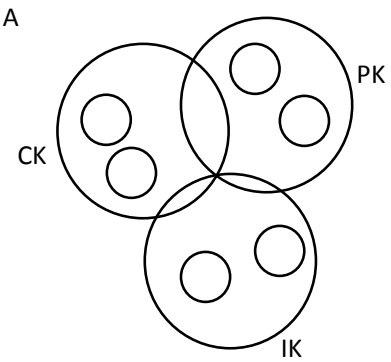

Model C

Figure 2. Integration Curriculum Models in Biology Islamic Education of State Islamic Universities.

Model A shows that there are two clusters which integrate to form Pedagogy Content Knowledge (PCK). The courses which belong to PCK clusters are Biology learning and curriculum; Biology teaching and learning strategy, media, and evaluation. PCK courses focus on how to teach Biology content to senior high school students. In this model, the courses on the knowledge of Islam related to content and pedagogical knowledge. However, the integration of the knowledge of Islam to PCK is left to each of the students.

Model B shows courses which integrate Pedagogy Content Knowledge (PCK) and Content Islamic Knowledge (CIK). The specific course which accomodates CIK missions is called The Integration of Islam and Science (2 credits).
The model has not showed the integration of the knowledge of Islam and Pedagogy yet.

Model C shows that it has already had PCK (Pedagogy Islamic Knowledge), CIK (Content Islamic Knowledge), and PIK (Pedagogy Islamic Knowledge). CIK is characterized by the avalaibility of Islam and Science course. Whereas, PIK is characterized by the course of Islamic Education Science.

The integration of Islam in the lectures conducted by Biology education lecturers is described as follows;1)The verse of the Quran is used at the beginning of the lecture as an introduction to the concept of Biology; 2) Some biological content can be attributed to the Quran verses or hadith as legitimacy that the phenomena in biology content have been described in the Quran and hadith; 3) Biological phenomena serve as a reflection to reinforce belief in God's creation (Aqida) and to improve the quality in carrying out the activties on earth better (Akhlak); 4) There are some biological phenomena, especially biotechnology that associated to shara law; 5) In the course of Pedagogy Knowledge, Islamic integration is conducted by studying the figures in Islamic education, the codification of verses related to education, and observation to schools which have Islamic caracteristics.

The students who were having internships at schools/madrasa undertook the integration in the following actions; 1) Insertion of Quran verses or hadith in the apperception step (The opening of teaching and learning process); 2) The insertion of the teaching and learning process is carried out for certain biological content that has congruence with Quran verses or hadith; 3) Reflection was conducted by relating content to Islamic values so it would improve the learners' faith (aqida) and morals (akhlak); 4) Embedding Islamic values (akhlak) at the time of biology practicum. 
TARBIYA: Journal of Education in Muslim Society, 4(2), 2017

Table 3. Subjects Course of Content Knowledge

\begin{tabular}{|c|c|c|c|c|c|c|c|c|}
\hline Uni & Biology Knowlec & & & & & & & Credits \\
\hline $\begin{array}{l}\text { versi } \\
\text { ty }\end{array}$ & $\begin{array}{l}\text { Biology Cell } \\
\text { and Molecular }\end{array}$ & Fisiology & Genetics & $\begin{array}{l}\text { Structure and } \\
\text { Development }\end{array}$ & $\begin{array}{l}\text { Biosystematics } \\
\text { and Evolution }\end{array}$ & Ecology & Others & \\
\hline 1 & $\begin{array}{l}\text { Microbiology } \\
\text { (3) } \\
\text { Biology Cell (2) }\end{array}$ & $\begin{array}{l}\text { Animal } \\
\text { Physiology (3) } \\
\text { Plant Physiology } \\
\text { (3) Anatomy and } \\
\text { Human } \\
\text { Physiology (2) } \\
\text { Embryology (3) }\end{array}$ & $\begin{array}{l}\text { Genetics } \\
\text { (3) } \\
\text { Biotechn } \\
\text { ology (3) }\end{array}$ & $\begin{array}{l}\text { Plant Morphology } \\
\text { (3) } \\
\text { Animal Structure } \\
\text { (3) } \\
\text { Plant Anatomy (3) }\end{array}$ & $\begin{array}{l}\text { Botanic } \\
\text { Crytogamae (3) } \\
\text { Botanic } \\
\text { Phaenerogamae } \\
\text { (3) } \\
\text { Zoology } \\
\text { Invertebrate (3) } \\
\text { Zoology } \\
\text { Vertebrata (3) } \\
\text { Evolution (2) }\end{array}$ & $\begin{array}{l}\text { Fundamental } \\
\text { Ecology (3) } \\
\text { Environmental } \\
\text { Science (2) }\end{array}$ & $\begin{array}{l}\text { General } \\
\text { Biology (2) }\end{array}$ & 52 \\
\hline 2 & $\begin{array}{l}\text { Microbiology } \\
\text { (3) } \\
\text { Biology cell and } \\
\text { molecular (2) }\end{array}$ & $\begin{array}{l}\text { Animal } \\
\text { Physiology (3) } \\
\text { Plant Physiology } \\
\text { (3) }\end{array}$ & $\begin{array}{l}\text { Genetics } \\
\text { (3) } \\
\text { Biotechn } \\
\text { ology }(2)\end{array}$ & $\begin{array}{l}\text { Plant structure and } \\
\text { development (4) } \\
\text { Animal structure } \\
\text { and development } \\
\text { (4) } \\
\text { Plan Embryology } \\
\text { and reproduction } \\
\text { (3) } \\
\text { Animal } \\
\text { Embryology (3) }\end{array}$ & $\begin{array}{l}\text { Evolution }(2) \\
\text { Plant systematics } \\
\text { (4) } \\
\text { Animal systematics } \\
\text { (4) }\end{array}$ & $\begin{array}{l}\text { Environmental } \\
\text { science (2) } \\
\text { Ecology (3) } \\
\text { Environmental } \\
\text { management (2) } \\
\text { Biology } \\
\text { Conservation (2) }\end{array}$ & $\begin{array}{l}\text { Bioethics } \\
(2) \\
\text { Biostatistics } \\
(2)\end{array}$ & 53 \\
\hline 3 & $\begin{array}{l}\text { Biology cell (3) } \\
\text { Microbiology } \\
\text { (3) }\end{array}$ & $\begin{array}{l}\text { Biology function } \\
\text { (3) } \\
\text { Plant Physiology } \\
\text { (3) } \\
\text { Animal } \\
\text { Physiology (3) }\end{array}$ & $\begin{array}{l}\text { Genetics } \\
\text { (3) } \\
\text { Introduct } \\
\text { ion to } \\
\text { Biotechn } \\
\text { ology (3) }\end{array}$ & $\begin{array}{l}\text { Plant anatomy and } \\
\text { morphology (3) }\end{array}$ & $\begin{array}{l}\text { Taxonomy lower } \\
\text { plant (3) } \\
\text { Taxonomy higher } \\
\text { plant (3) } \\
\text { A vertebrata (3) } \\
\text { Vertebrata (3) } \\
\text { Introduction to } \\
\text { evolution (2) }\end{array}$ & $\begin{array}{l}\text { Fundamental } \\
\text { Ecology (3) } \\
\text { Environmental } \\
\text { issues in Indonesia } \\
(2) \\
\text { Environmental } \\
\text { ethics (2) } \\
\text { Bioremediation (3) } \\
\text { Introduction to bio } \\
\text { conservation (3) }\end{array}$ & $\begin{array}{l}\text { Fundament } \\
\text { al } \\
\text { Biology(3) }\end{array}$ & 55 \\
\hline
\end{tabular}

${ }^{*}$ numbers of brackets show credits in semester

Table 4. Subject Course of Pedagogy Knowledge

\begin{tabular}{|c|c|c|c|c|c|}
\hline University & Curriculum & Teaching Method & $\begin{array}{l}\text { Cognitive and Affective } \\
\text { Skill }\end{array}$ & Others & Credits \\
\hline 1 & - & $\begin{array}{l}\text { Education Science (2) } \\
\text { Learning media and } \\
\text { communication } \\
\text { information technology (2) }\end{array}$ & $\begin{array}{l}\text { Counseling guidance (2) } \\
\text { Children Development (2) }\end{array}$ & $\begin{array}{l}\text { Philosophy of education (2) } \\
\text { Professional } \quad \text { Teacher } \\
\text { Development (2) } \\
\text { Education management (2) }\end{array}$ & 12 \\
\hline 2 & $\begin{array}{l}\text { Study of curriculum and } \\
\text { school problems }(2)\end{array}$ & - & $\begin{array}{l}\text { Educational Psychology (2) } \\
\text { Counseling guidance (2) }\end{array}$ & Education management (2) & 8 \\
\hline 3 & Curriculum and Learning (2) & & Educational Psychology (3) & $\begin{array}{l}\text { Educational Philosophy (2) } \\
\text { Education management (2) }\end{array}$ & 9 \\
\hline
\end{tabular}

${ }^{*}$ numbers of brackets show credits in semester

Table 5. Subjects Course of Islamic Knowledge

\begin{tabular}{|c|c|c|c|c|c|}
\hline Universiy & Aqidah & Syariah & Ahlaq & Others & Jumlah \\
\hline 1 & Tawheed (2) & $\begin{array}{l}\text { Ulumul Qur'an (2) } \\
\text { Ulumul Hadits (2) } \\
\text { Fiqh (2) } \\
\text { Ibadah practice (0) } \\
\text { Tilawah practice }(0)\end{array}$ & Akhlak (2) & $\begin{array}{ll}\text { Islamic } & \text { history and } \\
\text { civilization }(2) & \end{array}$ & 12 \\
\hline 2 & Tawheed (2) & $\begin{array}{l}\text { Al Qur'an dan Hadits (3) } \\
\text { Fiqh dan Ushul Fiqh (2) }\end{array}$ & $\begin{array}{l}\text { Akhlaq- } \\
\text { Tasawuf } \\
\text { (2) }\end{array}$ & $\begin{array}{l}\text { Religious } \\
\text { program (2) }\end{array}$ & 11 \\
\hline 3 & - & $\begin{array}{l}\text { Qur'an \& Hadist (2) Ibadah practice (1) } \\
\text { Qiroah practice (1) }\end{array}$ & Akhlak (3) & Islamic Study (4) & 11 \\
\hline
\end{tabular}

${ }^{*}$ numbers of brackets show credits in semester 
Table 6. Subject Courses of Pedagogy Content Knowledge

\begin{tabular}{|c|c|c|c|c|c|c|}
\hline University & Curriculum & $\begin{array}{l}\text { Teaching } \\
\text { Methodology }\end{array}$ & $\begin{array}{l}\text { Assesment and } \\
\text { evaluation }\end{array}$ & Learning media & Others & Credits \\
\hline 1 & $\begin{array}{l}\text { Curriculum and } \\
\text { learning of biology } \\
\text { (3) }\end{array}$ & $\begin{array}{l}\text { Study and learning } \\
\text { of biology (3) } \\
\text { Planning of biology } \\
\text { learning (3) } \\
\text { Microteaching (2) } \\
\text { Professional practice (4) }\end{array}$ & $\begin{array}{l}\text { Evaluastion of } \\
\text { biology learning } \\
\text { (3) }\end{array}$ & & $\begin{array}{l}\text { Biology selected topics for } \\
\text { secondary school }(4)\end{array}$ & 19 \\
\hline 2 & - & $\begin{array}{l}\text { Strategy of biology } \\
\text { learning (2) } \\
\text { Planning of biology } \\
\text { learning (2) } \\
\text { Study and learning } \\
\text { of biology (2) } \\
\text { Microteaching (2) } \\
\text { Professional practice (2) }\end{array}$ & $\begin{array}{l}\text { Evaluation of } \\
\text { biology learning } \\
\text { (3) }\end{array}$ & $\begin{array}{l}\text { Media and } \begin{array}{r}\text { Resource } \\
\text { learning }\end{array} \\
\text { biology } \\
\text { development (4) }\end{array}$ & - & 17 \\
\hline 3 & $\begin{array}{l}\text { Biology Curriculum } \\
\text { Study (2) }\end{array}$ & $\begin{array}{l}\text { Planning of biology } \\
\text { learning (3) } \\
\text { Strategy of biology } \\
\text { learning (3) } \\
\text { Microteaching (3) } \\
\text { Educational practice (4) }\end{array}$ & $\begin{array}{l}\text { Evaluation of } \\
\text { biology learning } \\
\text { (3) }\end{array}$ & $\begin{array}{l}\text { Media and technology of } \\
\text { biology learning (3) }\end{array}$ & $\begin{array}{l}\text { Environmental Education } \\
(2) \\
\text { Biology selected topics for } \\
\text { secondary school (3) }\end{array}$ & 26 \\
\hline
\end{tabular}

*numbers of brackets show credits in semester

Table 7. Subject course of Pedagogy Content Islamic Knowledge

\begin{tabular}{lllll}
\hline University & Pedagogy Islamic Knowledge & Content Islamic Knowledge & Pedagogy Content Islamic Knowledge & Jumlah \\
\hline $\mathbf{1}$ & - & - & - & 0 \\
$\mathbf{2}$ & - & Islam and science integrated (2) & - & 2 \\
$\mathbf{3}$ & Islamic Education Science (2) & Islam and science integrated (2) & - & 4 \\
\hline
\end{tabular}

${ }^{*}$ numbers of brackets show credits in semester

\section{Discussion}

The data collected from documents and several other sources. It can be inferred that the integration of Islamic knowledge into the content knowledge, pedagogy, and content pedagogy is textual, daily Islamic cultural, and reflective. Meanwhile, science has three components, i.e. concept, process, and values. According to this, the integration of Islam in Biology education program can be textual conceptual, have islamic scientific process and character value.

Textual conceptual is to bring up Islamic integration apparently in both lecture plans and teaching materials. According to the result of the document analysis of study program curriculum as well as the interview with the head of study program, textually the curriculum model produced is B, C, and D models (see Figure 4.1). On the result of the document analysis and the interview with the head of study program, an ideal model like $\mathrm{E}$ model was not found. Nevertheless, based on the results of questionnaires from students and lecturers, Biology education program can develop the ideal model. E model should expose the portion of PIK (Pedagogy Islamic Knowledge), CIK (Content Islamic Knowledge), and PCK (Pedagogy Islamic Knowledge), and the most important one is the portion of Pedagogy Content Islamic Knowledge (PCIK). According to data triangulation from curriculum document, the head of study program, lecturers and students; textually the course consists of the portions PIK, PCK, CIK, and PCIK as it can be seen in Table 8. According to the triangulation, there were three courses that capable of integrating Pedagogy Content Islamic Knowledge (PCIK), i.e. Microteaching, School Field Practice, and Capita Selecta of Biology. The courses have been run well, however; the integration pattern was only focused on PCK. Therefore, if Biology education program only focuses on PCK, it will be no different to the other teacher training institutes under Directorate of Islamic Higher Education (DIHE). If the notion of PCIK is made, then it 
will be the caharcteristics of Biology Islamic Education

Table 8. Biology Islamic Education Curriculum Triangulation Results

\begin{tabular}{|c|c|c|c|c|}
\hline $\mathrm{NO}$ & CIK & PIK & PCK & PCIK \\
\hline 1. & $\begin{array}{l}\text { Animal } \\
\text { Embryology/Animal } \\
\text { Re-production }\end{array}$ & $\begin{array}{l}\text { Islamic } \\
\text { edu- } \\
\text { cation } \\
\text { Science }\end{array}$ & $\begin{array}{l}\text { Biology } \\
\text { Curriculum }\end{array}$ & $\begin{array}{l}\text { Micro } \\
\text { teaching }\end{array}$ \\
\hline 2. & $\begin{array}{l}\text { Bio-technology \& } \\
\text { Bioethics }\end{array}$ & & $\begin{array}{l}\text { Biology } \\
\text { Learning } \\
\text { Strategy }\end{array}$ & $\begin{array}{l}\text { School } \\
\text { Field } \\
\text { Practice }\end{array}$ \\
\hline 3. & $\begin{array}{l}\text { Plants Diversity and } \\
\text { Systematics }\end{array}$ & & $\begin{array}{l}\text { Biology } \\
\text { learning } \\
\text { resources, } \\
\text { media, and } \\
\text { technology }\end{array}$ & $\begin{array}{l}\text { Capita } \\
\text { Selectea } \\
\text { of } \\
\text { Biology }\end{array}$ \\
\hline 4. & $\begin{array}{l}\text { Animals Diversity } \\
\text { and Systematics }\end{array}$ & & $\begin{array}{l}\text { Biology } \\
\text { evaluation } \\
\text { and } \\
\text { assessment }\end{array}$ & \\
\hline $\begin{array}{l}5 . \\
6 .\end{array}$ & $\begin{array}{l}\text { Ecology } \\
\text { Knowledge and } \\
\text { Science }\end{array}$ & & & \\
\hline
\end{tabular}

In the scientific process, Biology relies on scientific method which consists of (1) asking a question, (2) Finding inormation by doing some background research, (3) constructing a hypothesis, (4) doing an experiment, (5) collecting observation result and analyzing the data, and (6) drawing a conclusion(Helmenstine, 2017). The method in Quran generally begins by a command in understanding the nature, for example:

"Then do they not look at the camels how they are created?" (QS. Al - Ghaasyiyah: 17)

The purpose of the command in nature observation is to strengthen the belief on the existence and the power of God, in the other words to believe that God is The Creator (khalik) and The Director (mudabbir). Meanwhile, the objective of science which includes Biology is to answer the questions about natural phenomena.

Islamic scientific process defines as employing scientific methods to answer the questions related to natural phenomena so that it can increase the belief that God is The Creator (khalik) and The Director (mudabbir). Thus, islamic scientific process did not stop merely on "the answer of natural phenomena on emprical evidences", yet it brought back a critical reflective questions on "Why was it created? or why was the process directed by God? What are its benefits to humans, other living things as well as the nature?". The result of the analysis on the answer from lecturers of Biology education showed critical reflective process was carried out in integrating Islam into learning, especially in integrating Content Islamic Knowledge (CIK). Islamic scientific process consists of seven steps besides the six steps mentioned before (Helmenstine, 2017). The seventh step is doing reflection (muhasabah) over the phenomenon found or reflective critical thinking about the significance of phenomena created by God.

The scientists always instill the following values, i.e. scepticism, curiosity, objectivity, accuracy, and responsibility on the decisions ( Committee on Science, engineering, and public policy. 1998). Meanwhile, the values embedded in each moslem are thruthfulness (sidiq), advocacy (tablig), trustworthiness (amanah), and wisdom (fatonah). The vaule of character or morals is a universal values instilled by all people. The values is natural part that must be undertaken by all human beings. Therefore, this part is invisible in the integration conveyed by the research subjects.

\section{Conclusion}

Integration among pedadogy knowledge, content and Islam which is also known as Pedagogy Content Islamic Knowledge (PCIK) conceptually and textually portrayed integrated curriculum model. The knowledge of Islam intersected content knowledge (Biology) and emerged certain course, i.e. Islam and Science. The course presented at the time of lectures for biological fields that are fretile to relevant verses as the followings: (1) animal embryology/ 
reproduction, (2) plants and animas diversity and systematics, (3) ecology, and (4) biotechnology and bioethics. The knowledge of Islam intersected pedadogy and emerged Science of Islamic Education course. Pedagogy intersected Biology, thus emerged the following courses (1) Biology curriculum, (2) Biology learning strategy, (3) Biology learning sources, technology and media, and (4) Biology assessment and evaluation. The alignment of pedagogy knowledge, content, and Islam can be seen in the construction of teaching materials in capita selecta and practice undertaken by students through microteaching and school field practice.

Despite being conceptual and textual, integration of Islam was also seen on scientific process. In Biology Education program, scientifc process covers seven steps, i.e. (1) ask a question, (2) Find information by doing some background research, (3) construct a hypothesis, (4) do an experiment, (5) collect observation result and analyze the data, (6) draw a conclusion, and (7) think critically and reflectively about the signifance of phenomena created by God. The scientific process is not merely a value-free process, but also a spiritual process in glorifying The Creator of the universe.

Acknowledgment, the researcher would like to thank the Reseach Center for the support offered to this reseach through DIPA Syarif Hidayatullah State Islamic University Jakarta in 2017.

\section{References}

Anas, N., Alwi, EAZE., Subki, MHHREN., Bakar, NAA. (2013). The Integration of Knowledge in Islam: Concept and Challenges. Global Journal of Human Social Science Linguistics \& Education. 13(10).

Committee on Science, engineering, and public policy. (1998). On Being Scientist
Reponsible Conduct in Research. Washington: National Academic Press.

Helmenstine, A.M. (2017). 6 Steps of The Scientific Method. Retrieved from https://www.thoughtco.com/steps-of-thescientific-method-p2-606045

Juttner, M., Boone, W., Park, S., \& Neuhaus, B.J. (2013). Development and Use of a Test Instrument to Measure Biology Teachers'Content Knowledge (CK) and Pedagogical Content Knowledge (PCK). Educational Assesment Evaluation Accoutability. 25: 45-67

Kazemi, F. \& Rafiepour, A. (2017). Developing a Scale to Measure Content Knowledge and Pedagogy Content Knowledge of In Service Elementary Teachers on Fractions. International Journal of Science and Mathematics Education. 15(1): 1-21.

Shulman, L. (1987). Knowledge and Teaching: Foundations of the new reform. Harvard Education Review. 57 (1), pp.1-21.

Song, A.An. (2017). Preservice Teacher's Knowlwedge of Interdiciplinary Pedagogy: The Case of Elementary Mathematics Science Integrated Lessons. ZDM Mathematics Education. 49: 237-248.

Park, S. \& Oliver, J.S. (2008). Revisiting the Conceptualisation of Pedagogy Content Knowledge (PCK): PCK as a conceptual tool to understand teacher as professionals. Reserch Sicence Education. 38:261-284.

Park, S., Jang, J.Y., Chen, Y.C., \& Jung, J. (2011). Is Pedagogical Content Knowledge (PCK) Necessary for Reformed Science Teaching?: Evidence from empirical study. Research Sicence Education. 41: 245-260. 